\title{
FAKTOR-FAKTOR YANG MEMPENGARUHI PRODUKSI CABAI MERAH
}

\author{
Oleh: \\ SRI AYU ANDAYANI \\ FAKULTAS PERTANIAN UNIVERSITAS MAJALENGKA \\ email: sri.ayuandayani@yahoo.com
}

\begin{abstract}
Abstrak
Penelitian ini bertujuan untuk mengetahui pengaruh dan penggunaan faktor-faktor produksi terhadap produksi cabai merah. Penelitian telah dilaksanakan di Kecamatan Argapura Kabupaten Majalengka Jawa Barat dengan menggunakan pendekatan survey melalui analisis deskriptif kuantitatif. Pengambilan sampel petani cabai merah melalui simple random sampling dengan jumlah 33 orang. Hasil penelitian menunjukkan bahwa penggunaan faktor produksi pada usahatani cabai merah di daerah penelitian masih didasarkan pada minat dan pengalaman para petani, penggunaan faktor produksi masih belum sesuai dengan anjuran atau rekomendasi. Faktor produksi lahan, bibit, pupuk, pestisida, dan tenaga kerja secara serempak berpengaruh nyata terhadap produksi cabai merah sedangkan secara parsial faktor produksi pupuk, pestisida, dan tenaga kerja berpengaruh terhadap produksi tetapi faktor produksi lahan dan bibit tidak berpengaruh nyata terhadap produksi cabai merah.
\end{abstract}

Kata Kunci: faktor produksi, produksi, cabai merah

\begin{abstract}
This research aims to determine the influence and use of factors of production to the production of red chilli. Research has been conducted in the district of Majalengka, West Java Argapura using survey approach through quantitative descriptive analysis. Sampling red chili farmers through simple random sampling with 33 people. The results of this research showed that the use of factors of production in the red chili farming in the area of research is still based on interests and experience of the farmers, the use of factors of production are still not in accordance with the advice or recommendations. Production factors of land, seed, fertilizer, pesticides, and labor simultaneously significant effect on the production of red chilli while partial factors of production of fertilizers, pesticides and labor affect the production but production factors of land and seed did not significantly affect the production of red chilli.
\end{abstract}

Keywords: factors of production, production, red chilli

\section{PENDAHULUAN}

Hortikultura merupakan salah satu tanaman sebagai bahan pangan yang cukup penting bagi kebutuhan masyarakat sehingga perlu ditingkatkan produksinya untuk memenuhi kebutuhan secara nasional. Konsumsi terhadap produk hortikultura terus meningkat sejalan dengan bertambahnya penduduk, peningkatan pendapatan dan pengetahuan masyarakat terhadap gizi dan kesehatan. Dengan demikian pertanian hortikultura sudah seharusnya mendapat perhatian yang serius terutama menyangkut aspek produksi dan pengembangan sistem pemasarannya (Sugiarti, 2003).

Sektor hortikultura mempunyai peran yang strategis dalam mendukung pertumbuhan ekonomi nasional. Salah satu tanaman hortikultura yang mempunyai nilai ekonomis tinggi dan komersial adalah tanaman cabai merah. Tanaman cabai merah ini mempunyai posisi yang cenderung semakin penting dalam pola konsumsi makanan yaitu sayuran atau bumbu masakan sehari-hari maka dari itu cabai merah berindikasi memliki peluang pasar yang semakin luas baik itu untuk memenuhi permintaan konsumsi rumah tangga maupun 


\section{A MIMBAR AgRIBISNIS}

ISSN 2460-4321

Volume 1 Nomor 3 Juli 2016

industri dalam negeri serta ekspor (Rukmana, 2002).

Selain itu beberapa alasan penting komoditi cabai merah perlu dikembangkan yaitu: (1) komoditi yang mempunyai nilai ekonomi tinggi (high economic value commodity), (2) komoditas unggulan nasional dan daerah, (3) menduduki posisi penting dalam menu pangan walaupun dalam jumlah kecil namun setiap hari dikonsumsi oleh banyak orang, (4) mempunyai manfaat yang cukup beragam dan sebagai bahan baku industri (RPJM, 2012).

Jawa Barat merupakan salah satu produsen terbesar di Indonesia bahkan menduduki posisi kedua tertinggi setelah Jawa Tengah dan Kabupaten Majalengka merupakan salah satu daerah penghasil cabai merah di Jawa Barat. Namun demikian, produksi cabai merah di Majalengka mengalami fluktuasi. Pada tahun 2010 produksinya mencapai 42.462 ton tetapi pada tahun 2011 mengalami perubahan yaitu 6.916 ton dan pada tahun 2012 menjadi 9.651 ton (Dinas Pertanian Majalengka, 2012).

Kebutuhan cabai merah perkapita berada pada kisaran $3 \mathrm{~kg} / \mathrm{kapita} /$ tahun sehingga jika jumlah penduduk Indonesia sebanyak 250 juta maka pertahunnya dibutuhkan sebanyak 750.000 ton dan jumlah sebanyak itu diprediksikan belum dapat dipenuhi oleh produksi dalam negeri sehingga pemerintah sebagian melakukan impor (Siahaan et al, 2016). Begitu pula dengan Kabupetan Majalengka jumlah produksi cabai yang dihasilkan belum dapat memenuhi kebutuhan konsumsi masyarakat dan keberlanjutan produksinya belum terjadi. Terjadi fluktuasi produksi disebabkan oleh berbagai faktor salah satu diantaranya yaitu terjadinya anomali iklim yang mengakibatkan adanya hama dan penyakit serta gagal panen, begitu juga dengan sumber daya manusianya dalam pengelolan usahatani cabai merah.

Selain itu, permasalahan belum maksimalnya produksi cabai merah dikarenakan kombinasi dari masukan-masukan yang dilakukan petani berpengaruh terhadap produksi cabai merah. Dalam pencapaian produksi yang tinggi, faktor produksi merupakan satu kesatuan yang tidak dapat dipisahkan dalam melakukan usahatani cabai merah sehingga diperlukan ketepatan dalam mengkombinasikan faktorfaktor produksinya. Hasil penelitian Saptana (2011) menjelaskan bahwa implikasi kebijakan dalam meningkatkan efisiensi produksi dan mereduksi petani dalam menghindari risiko produktivitas diantaranya yaitu: (1) alokasi penggunaan faktor produksi secara lebih efisien, memperbaiki struktur pasar input dan output, (2) meningkatkan produktivitas dapat dilakukan dengan inovasi teknologi baru dan adaptasinya ditingkat petani.

Berdasarkan uraian di atas, jika tidak tepat dalam penggunaan faktor produksi maka kemungkinan produksi yang dihasilkan secara ekonomi tidak menguntungkan, maka tujuan yang diharapkan dari penelitian ini adalah untuk mengetahui pengaruh dan penggunaan faktorfaktor produksi terhadap produksi cabai merah di Kabupaten Majalengka.

\section{KAJIAN PUSTAKA \\ Usahatani}

Usahatani mempunyai arti yang sangat penting dalam pertanian dimana usahatani adalah suatu tempat di permukaan bumi ini dimana kegiatan pertanian diselenggarkan. Suatu usahatani dapat diukur dari nilai mutlak pendapatan dan tingkat keberhasilannya. (Suratiyah, 2009).

Dapat dikatakan pula bahwa usahatani adalah ilmu yang mempelajari bagaimana seseorang mengusahakan dan megkoordinir faktor-faktor produksi berupa lahan dan alam sebagai modal sehingga memberikan manfaat yang baik. Sebagai ilmu pengetahuan, ilmu usahatani merupakan ilmu yang mempelajari cara-cara petani menentukan, mengorganisasikan, dan mengkondisikan penggunaan faktor-faktor produksi seefektif dan seefisien mungkin sehingga usaha tersebut memberikan pendapatan yang maksimal (Soekartawi, 1986).

\section{Produksi dan Fungsi Produksi}

Faktor produksi adalah sumber daya yang digunakan dalam sebuah proses produksi. Fungsi produksi dapat menunjukkan sifat hubungan antara faktor-faktor produksi dan tingkat produksi yang dihasilkan. Dalam 
analisis ini dapat dimisalkan jika salah satu input produksi merupakan satu-satunya faktor produksi yang dapat diubah sedangkan faktor produksi lainnya dianggap tetap atau tidak mengalami perubahan (Soekartawi, 2003).

Salah satu model fungsi produksi yang digunakan dalam analisis usahatani adalah faktor produksi Cobb-Douglas. Secara matematis model ini dapat digambarkan sebagai berikut:

$$
\begin{aligned}
\mathrm{Y}=\mathrm{b}_{0} \mathrm{X}_{1}{ }^{\mathrm{b} 1} \mathrm{X}_{2}{ }^{\mathrm{b} 2} \ldots \mathrm{X}_{\mathrm{n}}^{\mathrm{bn}} \mathrm{e}^{\mathrm{u}}, \\
\text { dimana }: \mathrm{Y}=\text { hasil produksi } \\
\mathrm{X}_{\mathrm{n}}=\text { nilai faktor produksi ke- } \mathrm{n} \\
\mathrm{b}_{0}=\text { intersep } \\
\mathrm{b}_{\mathrm{n}}=\text { dugaan slope yang berhubungan } \\
\text { dengan variable } \mathrm{X}_{\mathrm{n}} \\
\mathrm{e}=\text { bilangan natural } \\
\mathrm{u}=\text { kesalahan (residual) }
\end{aligned}
$$

\section{METODE PENELITIAN}

Desain penelitian ini menggunakan desain penelitian kuantitatif dengan jenis penelitian survey dan teknik analisis deskriptif. Lokasi penelitian di Kecamatan Argapura Kabupaten Majalengka. Dalam mengambil responden, penelitian ini menggunakan teknik probability sampling dimana pada teknik ini semua populasi mempunyai peluang yang sama untuk dijadikan sampel. Jenis sampling yang dipilih adalah simple random sampling dan yang dijadikan sampelnya adalah 33 orang.

Analisis yang digunakan dalam mengetahui pengaruh penggunaan faktor produksi baik secara serempak maupun parsial terhadap produksi cabai merah maka dilakukan teknik analisis dengan menggunakan fungsi produksi model cob-douglas dengan formula:

$\mathrm{Q}=\operatorname{bo} \mathrm{X} 1^{\mathrm{b} 1} \mathrm{X} 2^{\mathrm{b} 2} \times 3^{\mathrm{b} 3} \times 4^{\mathrm{b} 4} \times 5^{\mathrm{b} 5}$

Dalam bentuk logaritma ganda, persamaan tersebut dapat diformulasikan sebagai berikut:

Log Produk $=\mathrm{b} 0+\mathrm{b} 1 \log$ lahan $+\mathrm{b} 2 \log$ bibit + b3 log tenaga kerja + b4 log pupuk + b5 log pestisida

Dimana: Q (produksi cabai merah), $\mathrm{X}_{1}$ (lahan dalam hektar), $X_{2}$ (bibit dalam $\mathrm{kg}$ ), $\mathrm{X}_{3}$ (tenaga kerja dalam $\mathrm{HOK}$ ), $\mathrm{X}_{4}$ (pupuk dalam $\mathrm{kg}$ ), $\mathrm{X}_{5}$ (pestisida dalam $\mathrm{kg}$ atau liter), bo: konstanta merupakan tingkat produksi simultan, b1: pangkat merupakan koefisien elastisitas produksi dalam persen untuk masing-masing input. Teknik perhitungan dianalisis dengan menggunakan program SPSS versi 17, baik secara serempak maupun secara mandiri. Alat uji yang digunakan untuk menguji apakah variable bebas (X) secara serempak berpengaruh terhadap variable tidak bebas (Y) adalah dengan menggunakan uji $\mathrm{F}$.

\section{Uji F}

Pengaruh variable bebas $\left(\mathrm{X}_{\mathrm{i}}\right)$, yaitu lahan $\left(\mathrm{X}_{1}\right)$, bibit $\left(\mathrm{X}_{2}\right)$, tenaga kerja $\left(\mathrm{X}_{3}\right)$, pupuk $\left(\mathrm{X}_{4}\right)$, pestisida $\left(\mathrm{X}_{5}\right)$ terhadap variable terikat $(\mathrm{Y})$ yaitu produksi cabai merah di tingkat petani secara simultan dapat diketahui dengan menggunakan uji $\mathrm{F}$ (F-test) dengan criteria pada signifikan $\mathrm{F}$ taraf $5 \%$, yaitu :

$\mathrm{F}_{\text {hit }}=\frac{\sum \text { kuadrat regresi }}{\sum \text { kuadrat residual }}$

(3)

dengan hipotesis:

Ho $\quad: b_{1}=b_{2}=b_{3}=b_{4}=b_{5}=0$, tidak ada pengaruh variable bebas $\left(\mathrm{X}_{\mathrm{i}}\right)$ secara simultan terhadap variable terikat $(\mathrm{Y})$

$\mathrm{H}_{1} \quad: \mathrm{b}_{1} \# \mathrm{~b}_{2} \# \mathrm{~b}_{3} \# \mathrm{~b}_{4} \# \mathrm{~b}_{5} \# 0$, terdapat pengaruh variable bebas $\left(\mathrm{X}_{\mathrm{i}}\right)$ secara simultan terhadap varibel terikat $(\mathrm{Y})$.

\section{Uji T}

Uji $t$ adalah untuk mengetahui pengaruh variable bebas $(\mathrm{Xi})$, yaitu lahan lahan $\left(\mathrm{X}_{1}\right)$, bibit $\left(\mathrm{X}_{2}\right)$, tenaga kerja $\left(\mathrm{X}_{3}\right)$, pupuk $\left(\mathrm{X}_{4}\right)$, pestisida $\left(\mathrm{X}_{5}\right)$ terhadap variable terikat $(\mathrm{Y})$, yaitu produksi cabai merah di tingkat petani secara individual (parsial), dengan syarat bahwa $\mathrm{t}$ hitung $>\mathrm{t}$ table dan jika nilai signifikan $\mathrm{t} \leq$ 0,05 pada taraf $5 \%$.

HASIL DAN PEMBAHASAN

\section{Penggunaan Faktor Produksi Usahatani Cabai Merah}

Faktor produksi yang digunakan dalam usahatani cabai merah adalah penggunaan luas lahan, bibit, pupuk, pestisida, dan tenaga kerja. Berdasarkan hasil penelitian bahwa luas lahan 


\section{AIMBAR AgRIBISNIS \\ ISSN 2460-4321}

Volume 1 • Nomor 3 • Juli 2016

yang digunakan untuk tanaman cabai merah bervariatif seperti disajikan dalam Tabel 1 .

Tabel 1. Penguasaan Lahan Petani

\begin{tabular}{cccc}
\hline No & $\begin{array}{c}\text { Penguasaan Lahan } \\
\text { (ha) }\end{array}$ & $\begin{array}{c}\text { Jumlah } \\
\text { (orang) }\end{array}$ & Persen (\%) \\
\hline 1 & $0,10-0,25$ & 20 & 60,60 \\
\hline 2 & $0,26-0,50$ & 11 & 33,33 \\
\hline 3 & $0,51-1,00$ & 1 & 3,35 \\
\hline 4 & $-\quad 1,00$ & 1 & 3,35 \\
\hline
\end{tabular}

Sumber: Data Primer

Berdasarkan hasil penelitian bahwa sebagian besar petani mengusahakan lahannya untuk ditanami cabai merah hanya rata-rata dikisaran $0,10-0,25$ ha dikarenakan beralihnya fungsi lahan pertanian menjadi tempat pemukiman atau perumahan ataupun banyak lahan yang berbukit-bukit dan hanya 1 orang petani yang dapat mengusahakan lebih dari 1 ha untuk tanaman cabai merah hal ini diprediksikan tidak akan dapat mengimbangi akan permintaan konsumsi masyarakat terhadap cabai merah.

Penggunaan faktor produksi lainnya yaitu bibit. Petani menggunakan bibit rata-rata sebanyak 6.227 pohon/rata-rata luas lahan dan 15.747,12 pohon/ha sedangkan jika melihat rekomendasi penggunaan bibit sebanyak 18.000 pohon/ha maka petani masih mengalami kekurangan sehingga dapat diprediksikan produksi tidak akan sesuai dengan harapan.
Begitu pula halnya dengan penggunaan pupuk masih jauh dari teknis anjuran atau rekomendasi. Pupuk organik hanya digunakan sebanyak $5.371 \mathrm{~kg} / \mathrm{ha}$ sedangkan kalau sesuai anjuran harus $25.000 \mathrm{~kg} / \mathrm{ha}$, pupuk ZA juga hanya menggunakan $418 \mathrm{~kg} / \mathrm{ha}$ sedangkan anjurannya $650 \mathrm{~kg} / \mathrm{ha}$ begitu pula dengan pestisida masih tidak sesuai aturan dan tenaga kerja pun masih kekurangan dikarenakan lebih banyak mencari pekerjaan menjadi tukang ojek, pekerja pabrik dan lain sebagainya yang dianggap tidak terlalu banyak menimbulkan risiko. Dengan demikian produksi yang diperoleh dari tanaman cabai merah masih jauh dari harapan para petani.

\section{Pengaruh Luas Lahan, Bibit, Pupuk, Tenaga Kerja, dan Pestisida Terhadap Produksi Cabai Merah}

\section{Uji F}

Pendugaan terhadap produksi cabai merah dilakukan dari luas lahan, jumlah bibit yang digunakan, jumlah pupuk organic dan anorganik yang digunakan (pupuk ayam postal, phonska, ZA, SP36 dan mutiara 16-16-16), pestisida serta jumlah tenaga kerja untuk satu musim tanam 2012. Hubungan antara faktor produksi (variable bebas) dengan produksi (variable terikat) dapat dilihat pada Tabel 2 berikut ini:

Tabel 2. Pengaruh Faktor Produksi Terhadap Produksi Cabai Merah ANOVA $^{b}$

\begin{tabular}{|c|c|c|c|c|c|}
\hline Model & Sum Of Squares & df & Mean Square & F & Sig \\
\hline Regression & 11.732 & 3 & 3.911 & 10686.404 & $.000^{\mathrm{a}}$ \\
Residual & .011 & 29 & .000 & & \\
Total & 11.742 & 32 & & \\
\hline
\end{tabular}

a. Predictors: (constant), X5,X3,X4

b. Dependent Variabel: Y

Berdasarkan hasil pengujian di atas menyatakan bahwa nilai $F_{\text {hitung }}$ dengan nilai significance kurang dari 0.05 . hal ini menunjukkan bahwa $\mathrm{H}_{0}$ ditolak dan hipotesis $\mathrm{H}_{1}$ diterima. Dengan demikian dapat dikatakan bahwa semua variable independen yaitu lahan
$\left(\mathrm{X}_{1}\right)$, bibit $\left(\mathrm{X}_{2}\right)$, tenaga kerja $\left(\mathrm{X}_{3}\right)$, pupuk $\left(\mathrm{X}_{4}\right)$, pestisida $\left(\mathrm{X}_{5}\right)$ secara simultan berpengaruh terhadap produksi cabai merah (Y). Hasil ini sesuai dengan pernyataan Soekartawi et al, 1986 bahwa produksi suatu tanaman sangat dipengaruhi oleh faktor produksi yaitu faktor 


\section{Faktor-Faktor Yang Mempengaruhi Produksi Cabai Merah \\ SRI AYU ANDAYANI}

lahan, tenaga kerja, pupuk, pestisida, dan teknologi.

\section{Uji t}

Hasil uji t dapat dilihat pada Tabel 3. Hasil uji t dari variable bebas lahan $\left(\mathrm{X}_{1}\right)$, bibit
$\left(\mathrm{X}_{2}\right)$, tenaga kerja $\left(\mathrm{X}_{3}\right)$, pupuk $\left(\mathrm{X}_{4}\right)$, pestisida $\left(\mathrm{X}_{5}\right)$ secara parsial berpengaruh nyata atau tidak berpengaruh nyata terhadap variable tidak bebas (Y) yaitu produksi pada tingkat petani cabai merah.

\section{Tabel 3. Hasil Pendugaan Parameter Analisi Regresi Antara Variabel Bebas terhadap variabel Tidak Bebas pada Usahatani Cabai Merah}

\begin{tabular}{|c|c|c|c|c|c|c|c|}
\hline \multicolumn{8}{|c|}{ Coefficients $^{\mathrm{a}}$} \\
\hline Model & \multicolumn{2}{|c|}{$\begin{array}{l}\text { Unstandardized } \\
\text { Coefficients }\end{array}$} & \multirow{2}{*}{$\begin{array}{c}\text { Standardized } \\
\text { Coefficients } \\
\text { Beta }\end{array}$} & \multirow{2}{*}{$\mathrm{t}$} & \multirow{2}{*}{ Sig } & \multicolumn{2}{|c|}{$\begin{array}{l}95,0 \% \text { Confidence } \\
\text { Interval for B }\end{array}$} \\
\hline & B & Std.Error & & & & $\begin{array}{l}\text { Lower } \\
\text { Bound }\end{array}$ & $\begin{array}{l}\text { Upper } \\
\text { Bound }\end{array}$ \\
\hline (Constant) & -3.736 & .534 & & -7.003 & .000 & -4.827 & -2.645 \\
\hline $\mathrm{X}_{3}$ (pupuk) & -.195 & .070 & -.192 & -2.770 & .010 & -.339 & -.051 \\
\hline $\mathrm{X}_{4}($ pestisida $)$ & 1.388 & .075 & 1.385 & 18.524 & .000 & 1.235 & 1.542 \\
\hline $\mathrm{X}_{5}$ (tenaga kerja) & -.275 & .091 & -.195 & -3.031 & .005 & -.460 & -.089 \\
\hline
\end{tabular}

a. Dependent Variable: Y

\begin{tabular}{|c|c|c|c|c|c|}
\hline \multirow{2}{*}{ Model } & \multirow{2}{*}{ Beta In } & \multirow{2}{*}{$\mathrm{t}$} & \multirow{2}{*}{ Sig } & \multirow{2}{*}{ Partial Correlation } & Colinearity Statistics \\
\hline & & & & & Tolerance \\
\hline $\begin{array}{ll}1 & \mathrm{X}_{1} \text { (lahan) } \\
& \mathrm{X}_{2} \text { (bibit) } \\
\end{array}$ & $\begin{array}{r}-.295^{\mathrm{a}} \\
-293^{\mathrm{a}} \\
\end{array}$ & $\begin{array}{l}-.382 \\
-.380 \\
\end{array}$ & $\begin{array}{l}.706 \\
.707 \\
\end{array}$ & $\begin{array}{l}-.072 \\
-.072 \\
\end{array}$ & $\begin{array}{l}5.391 \mathrm{E}-5 \\
5.375 \mathrm{E}-5 \\
\end{array}$ \\
\hline
\end{tabular}

a. Predictors in the model: (constant), X5,X3,X4

Berdasarkan hasil uji $\mathrm{t}$ pada Tabel 3 menunjukkan bahwa persamaan model regresi dari fungsi produksi cabai merah di tingkat petani di daerah penelitian secara umum dapat ditulis sebagai berikut:

Nilai $b 0=-3.736, b 1=-0,295, b 2=-0,293, b 3$ $=-0,195, \mathrm{~b} 4=1,388$ dan $\mathrm{b} 5=-0,275$

sehingga dari persamaan:

$\log$ Produk $=\mathrm{b} 0+\mathrm{b} 1 \log$ lahan $+\mathrm{b} 2 \log$ bibit + b3 log pupuk + b4 log pestisida + b5 log tenaga kerja

dapat dibuat persamaan regresi sebagai berikut: $\mathrm{Y}=-3.736-0,295 \mathrm{X}_{1}-0,293 \mathrm{X}_{2}-0,195 \mathrm{X}_{3}+$ $1.388 \mathrm{X}_{4}-0,275 \mathrm{X}_{5}$

\section{Pengaruh Lahan $\left(X_{1}\right)$ terhadap Produksi} Cabai Merah (Y)

Hasil perhitungan uji t pada lahan $\left(\mathrm{X}_{1}\right)$ terhadap produksi cabai merah $(\mathrm{Y})$ diperoleh $\mathrm{t}$ hitung luas lahan yaitu $-0,382$ dan nilai sig $0,706>0,05$ adalah non signifikan pada taraf sig $5 \%$ maka artinya $\mathrm{H}_{0}$ diterima sehingga faktor produksi lahan secara parsial tidak berpengaruh secara signifikan terhadap produksi cabai merah. Menurut Soekartawi et al, 1986 menegaskan kondisi lahan sangat berpengaruh terhadap produksi hasil pertanian termasuk cabai merah baik dilihat dari luasannya, tingkat kesuburan dan penggunaannya seperti lahan tegalan, lahan sawah, kebun dan lain sebagainya. Dengan demikian akan mempengaruhi pada harga sewa lahan tersebut, semakin tinggi tingkat produktivitas lahan maka semakin tinggi harga sewa lahan itu.

\section{Pengaruh Jumlah Bibit $\left(\mathbf{X}_{2}\right)$ terhadap Produksi Cabai Merah (Y)}

Hasil perhitungan uji t pada bibit $\left(\mathrm{X}_{2}\right)$ terhadap produksi cabai merah (Y) diperoleh $\mathrm{t}$ hitung variable bibit yaitu $-0,380$ dan nilai sig $0,707>0,05$ adalah non signifikan pada taraf signifikansi $5 \%$ artinya $\mathrm{H}_{0}$ diterima sehingga faktor produksi bibit secara parsial tidak 


\section{A MIMBAR AgRIBISNIS}

ISSN 2460-4321

Volume 1 - Nomor 3 Juli 2016

berpengaruh secara signifikan terhadap produksi cabai merah. Soekartawi et al, 1986 menjelaskan bahwa bibit merupakan cikal bakal terhadap hasil produksi tanaman sehingga jika bibit menggunakan yang unggul dan bersertifikat sangat mempengaruhi hasil produksinya yang semakin baik dan sebaliknya maka akan menghasilkan kualitas yang rendah dan rentan terhadap hama penyakit. Di daerah penelitian penggunaan bibit masih seadanya belum memikirkan penggunaan yang unggul sehingga hasilnya masih jauh dari harapan.

\section{Pengaruh Pupuk $\left(\mathrm{X}_{3}\right)$ terhadap Produksi Cabai Merah (Y)}

Hasil perhitungan uji t pada pupuk $\left(\mathrm{X}_{3}\right)$ terhadap produksi cabai merah $(\mathrm{Y})$ diperoleh $\mathrm{t}$ hitung variable pupuk yaitu -2.770 dan nilai sig $0,010<0,05$ adalah signifikan pada taraf signifikansi $5 \%$ artinya $\mathrm{H}_{0}$ ditolak sehingga faktor produksi pupuk secara parsial berpengaruh secara signifikan terhadap produksi cabai merah.

Penggunaan pupuk anorganik secara terus menerus akan menyebabkan residu yang kuat diikat oleh partikel tanah dan kekurangan bahan organic di dalam tanah dapat menyebabkan pupuk mudah terbawa air karena banjir atau air melimpah dan pada musim kemarau akan menimbulkan kekeringan sehingga pupuk tidak cukup tersedia untuk akar tanaman (Hardjowigeno, 2007). Aplikasi pupuk organik dan anorganik harus mempunyai keseimbangan di dalam tanah, di daerah penelitian walaupun penggunaan pupuk baik organic maupun anorganik masih belum sesuai dengan rekomendasi tetapi pengaplikasian sudah menunjukkan adanya keseimbangan hal ini terlihat dari pengalaman dan minat para petani cabai merah. Soekartawi et al, 1986 menjelaskan pula bahwa penggunaan pupuk menjadi faktor penentu dalam keberhasilan produksi komoditas pertanian.

\section{Pengaruh Jumlah Pestisida $\left(\mathbf{X}_{4}\right)$ terhadap Produksi Cabai Merah (Y)}

Hasil perhitungan uji t pada pestisida $\left(\mathrm{X}_{4}\right)$ terhadap produksi cabai merah (Y) diperoleh $\mathrm{t}$ hitung variable pestisida yaitu
18.524 dan nilai sig $0,000<0,05$ adalah signifikan pada taraf signifikansi $5 \%$ artinya $\mathrm{H}_{0}$ ditolak sehingga faktor produksi pestisida secara parsial berpengaruh secara signifikan terhadap produksi cabai merah.

Responden petani cabai merah menggunakan pestisida yang berbentuk tepung dan ada pula yang berbentuk larutan. Pestisida yang berbentuk tepung yaitu fungisida dengan dosis $14,45 \mathrm{~kg} / \mathrm{ha}$ sedangkan yang berbentuk larutan yaitu insektisida dengan dosis 2,21 liter/ha. Penggunaan pestisida tersebut sudah disesuaikan dengan keadaan atau kondisi tanaman di lapangan. Penerapan pengaplikasian pestisida sangat ditentukan pula oleh latar belakang dari sumber daya manusianya seperti pendidikan, pengetahuan, dan pengalaman. Hal ini diperkuat pula oleh pernyataan Siahaan, 1998 bahwa faktor yang mempengaruhi petani dalam proses adopsi inovasi dan pengendalian hama terpadu diantaranya yaitu: (1) karakter social ekonomi seperti pendidikan, (2) pembentukan persepsi seperti pengalaman, (3) komunikasi antar petani dan instansi terkait.

\section{Pengaruh Tenaga Kerja $\left(\mathrm{X}_{5}\right)$ terhadap Produksi Cabai Merah (Y)}

Hasil perhitungan uji $\mathrm{t}$ pada tenaga kerja $\left(\mathrm{X}_{5}\right)$ terhadap produksi cabai merah $(\mathrm{Y})$ diperoleh t hitung variable tenaga kerja yaitu 3.031 dan nilai sig $0,005<0,05$ adalah signifikan pada taraf signifikansi $5 \%$ artinya $\mathrm{H}_{0}$ ditolak sehingga faktor produksi tenaga kerja secara parsial berpengaruh secara signifikan terhadap produksi cabai merah.

Umur petani berperan sekali dalam pelaksanaan usahatani cabai merah, umur yang semakin lanjut akan mempengaruhi tingkat produktivitas petani yang semakin berkurang. Kondisi kelompok umur petani responden masih didominasi oleh kelompok umur produktif yaitu sekitar umur 30-39 tahun sebanyak 11 orang $(33,33 \%)$, umur 25-29 tahun sebanyak 2 orang $(6,06 \%)$, umur $40-44$ sebanyak 4 orang $(12,12 \%)$, umur $45-49$ sebanyak 2 orang $(6,06 \%)$ dan umur 50-54 sebanyak 4 orang $(12,12 \%)$ dan kenyataan ada umur responden lebih dari 54 tahun sebanyak 10 orang masih melakukan usahatani ini 
terdorong pengalaman mereka dalam berusahatani cabai merah.

Tenaga kerja yang terampil akan mempermudah dalam menerapkan teknologi tepat guna sesuai anjuran/rekomendasi termasuk dalam metode pengendalian hama terpadu (HPT). Rammadhan (2013) menjelaskan pula bahwa keputusan petani sangat menentukan dalam penggunaan input produksi termasuk dalam aplikasi benih unggul bersertifikat begitu pula dalam aplikasi pupuk berimbang.

\section{KESIMPULAN}

Penggunaan faktor produksi pada usahatani cabai merah masih didasarkan pada minat dan pengalaman para petani cabai merah, penggunaan bibit, pupuk organic dan anorganik, pestisida masih belum sesuai anjuran atau rekomendasi begitu pula dengan luas lahan yang ditanami cabai merah masih kisaran $0,10-0,25$ dikarenakan banyaknya alih fungsi lahan dan berbukit serta penggunaan tenaga kerja masih kekurangan.

Berdasarkan hasil analisis regresi linier berganda pada penelitian ini maka dihasilkan secara serempak faktor produksi lahan, bibit, pupuk, pestisida, dan tenaga kerja berpengaruh nyata terhadap produksi cabai merah sedangkan secara parsial faktor produksi pupuk, pestisida, dan tenaga kerja berpengaruh nyata terhadap produksi cabai merah tetapi untuk faktor produksi lahan dan bibit tidak berpengaruh terhadap produksi cabai merah.

Perlunya perhatian dari berbagai pihak seperti instansi terkait, para penyuluh pertanian, dan petani cabai merah pada faktor-faktor produksi yang berkaitan dengan budidaya cabai merah sehingga penggunaan faktor produksi lebih optimal dalam upaya keberlanjutan produksi cabai merah.

\section{DAFTAR PUSTAKA}

Dinas Pertanian dan Perikanan Kabupaten Majalengka, 2011. Laporan Tahun 2008-2012

Hardjowigeno, S. 2007. Ilmu Tanah. Cet

Keenam CV. Akademika

Pressindo. Jakarta
Rammadhan, F. 2013. Faktor-faktor yang Mempengaruhi Keputusan Pembelian Petani dalam Memilih Benih Padi Bersertifikat PT SHS (Sang Hyang Seri) di Kabupaten Bogor, Skripsi Departemen Agribisnis Fakultas Ekonomi Manajemen IPB.

Rukmana, R, 2002. Cabe Merah, Budidaya Pengolahan Pasca Panen, Kanisius Yogyakarta

Rencana Pembangunan Jangka Menengah Nasional (RPJM) bidang pangan dan pertanian, 2012. Direktorat pangan dan pertanian Kementerian perencanaan dan pembangunan nasional

Saptana, 2011. Efisiensi Produksi dan Perilaku Petani terhadap Risiko Produktivitas Cabai Merah di Jawa Tengah, IPB

Siahaan, D,S, Tarigan K, Sebayang T. 2016. Efisiensi Penggunaan Faktor Produksi Usahatani Cabai Merah. Agribisnis Faperta Universitas Sumatera Utara.

Siahaan, T.L., 1998. Faktor-faktor yang Mempengaruhi Petani dalam Mengadopsi Metode Pengendalian Hama Terpadu (kasus kelompok tani Di Desa Sibentang, Kecamatan Leuwiliang, Kabupaten Bogor Jawa Barat). Skripsi Jurusan Ilmu-Ilmu Sosial Ekonomi Pertanian, IPB

Soekartawi, A.S,J.L,Dillon, dan J.B Hardaker. 1986. Ilmu Usahatani dan Penelitian Untuk Pengembangan Petani Kecil. Cetakan Ketiga, Penerbit Universitas Indonesia, Salemba Jakarta.

Soekartawi, 2003. Teori Ekonomi Produksi dengan Pokok Bahasan Analisis CobbDouglas. Raja Grafindo Perkasa. Jakarta

Suratiyah, Ken. 2009. Ilmu Usahatani.Jakarta Penebar Swadaya

Sugiarti, S. 2003. Usahatani dan Pemasaran Cabai Merah. Jurnal Akta Agrosia, Vol.6 No. 1 (Januari-Juni): 23-27 Yogyakarta 


\section{A MIMBAR AgRIBISNIS \\ ISSN 2460-4321}

Volume 1• Nomor $3 \bullet$ Juli 2016

Halaman | 268 